\title{
Educational Attainment and Income Inequality: Evidence from Household Data of Odisha
}

\author{
Dr. Atal Bihari Das ${ }^{1}$, Dr. Dharmabrata Mohapatra ${ }^{2}$ \\ ${ }^{I}$ Department of Economics, Ravenshaw University, Cuttack, Odisha, India \\ ${ }^{2}$ Department of Economics, Ravenshaw University, Cuttack, Odisha, India
}

\begin{abstract}
This paper examines the impact of education on income inequality by gender, caste, region and occupation using primary data collected from sample households form two selected districts of Odisha by using the earnings function of Mincerian type (1962). The findings clearly show that there are income differences by gender, caste, occupation and region. Women, self employees, SC/STs and people in rural area earn less than their counterparts male, wage employees, upper caste people and people in urban area respectively. The return to education is higher for women, wage employees, SC/STS and people in rural area. The differences in return to education between gender, across caste and across region decline at higher levels of education in both the occupations. The differences in return to education across gender and region are very less for wage employees than in case of self employees. The paper concludes that education is one of the strong instruments for reducing the inequality in income in Odisha. In this backdrop our findings suggest that more educational opportunities to be provided in rural areas, special efforts to be taken to increase level of education of women and lower caste people. Further, Government should provide employment opportunities in rural areas to enhance work participation rate.
\end{abstract}

Key Words: Education, Income, Inequality, occupation and Odisha

\section{Introduction}

Inequality can manifest itself in all aspects of life including type and location of housing available, access to quality education and healthcare services and earning. In this paper we focused on why some groups of workers are significantly earn less compared to that of other population. It is observed that there is not only disparity in employment by gender but also differences in earnings among the educated workers. The earnings also differ among different sectors and types of work, between rural and urban areas and among different social groups of population. Within each group there is a striking difference in earnings between male and female. Despite many laws and regulations, there exist wage differentials between male and female workers and these differences are more pronounced in rural areas than in urban areas. This is largely on account of the imperfect labour market in the less developed/rural areas. The differential wage rate by gender and caste is determined by type, sector and location of work, socio-economic background, level of education, and the experiences of the workers, among other things. Economists have expressed differences of opinion in this respect. Freeman [1] argues that better educated workers receive higher income than the less educated ones, unionised industries pay a wage premium over the non-unionised ones, the urban wage rate is higher than the rural rate, and men are paid more than women. Mazumdar and Ahmed [2] state that the differences in earnings can be attributed to institutional factors after we have allowed for variations in measurable human quality factors like education and experiences. There are strong arguments in favour of denied opportunities to lower social groups which are deep rooted in caste system for generations (Thorat and Newman [3] and Jodhka and Shah [4]). There is a close association between education and earning as education enables a person to gain an entry into the labour market. Education is considered to be one of the contributing factors for higher earnings by increasing the productivity, skill and efficiency of the educated persons, which influences the overall quality of the labour. There is a substantial body of evidences showing that workers with higher levels of education are more likely to participate in the labour market, face lower risks of unemployment, have greater access to further training and receive higher earnings on an average. Becker [5], Mincer [6], Schultz [7], Tilak [8], Debi [9] and many others have found that education influences earnings of individuals significantly. Education also helps in narrowing down the gender gap by equalising the earnings between male and female workers (Debi and Das [10]. Thus, education plays a crucial role in reducing inequality in earning to a significant extent. However, opportunities for education could differ by gender, caste and region.

In this backdrop, this paper makes an attempt to examine the income inequality by gender and sector of work among the educated persons across social groups and across region with the help of an empirical study conducted in two districts of Odisha. The structure of the current paper is outlined as follows. The subsequent 
section details the research questions. Section III presents the analytical framework. Section IV presents the results and the last section concludes the paper.

\section{Research Questions}

[1] Is there any income difference by gender among the educated persons across social groups?

[2] What are the factors responsible for such income inequality?

[3] Does education help in reducing income inequality across region, caste and gender?

With the help of an empirical study, we have tried to seek answers to these questions in the context of a backward region in the state of Odisha.

\subsection{Data and sampling}

\section{Analytical Framework}

The present study is based mainly on the data collected through a sample survey conducted in two districts of Odisha on the basis of Human Development Index as estimated in Odisha Human Development Report 2004. The sample districts were the ones with the lowest and highest Human Development Index (HDI). Thus, Malakangiri (HDI 0.370) and Khurda (HDI 0.736) districts were selected. In the next stage, two blocks were chosen from each sample district, on the basis of their literacy rates. Two blocks with the highest and lowest literacy rates in the districts were selected. Such a selection will not only provide the average picture, but also give an idea about the spread of imbalances. In the next stage, three villages with highest tribal, SC and general population were selected in each of the sample block. Thus, 4 blocks and 12 villages were selected. Two urban centres were taken to reflect the urban labour market. In the next stage we selected 30 households from each village and 60 households from each urban centres. Thus a total of 480 households consisting of 360 households from the rural areas and 120 households from the urban areas were finally selected. Households across caste categories in a village and urban centre were sampled in proportion to the shares of various castes in total population. Again the earning members of the households were classified under two heads such as self employees and wage employees by gender, caste and region. All the relevant information was collected with the help of a structured household schedule through a field survey in the year 2012.

\subsection{The model}

The study used the earning function of Mincerian (Mincer, 1962) type to examine the questions raised earlier to assess the contribution of education to earnings. In the Mincerian model schooling and experience were used as the independent variable but in the present study we have not included experience instead we used age as one of the independent variables.

The following Mincerian earning function is used to examine the contribution of education to earnings.

Ln $W_{i}=\alpha+\beta_{1} S_{i}+\beta_{2} X_{i}+\beta_{3} X_{i}^{2}+U_{i}$

Where,

$\mathrm{W}_{\mathrm{i}}$ is the annual earnings for the individual in logarithm terms

$\alpha$ is the constant/intercept term,

$\mathrm{S}=$ years of schooling

$\mathrm{X}$ and $\mathrm{X}^{2}$ are age and its square respectively

$\mathrm{U}_{\mathrm{i}}=$ error term

The coefficients of schooling, age and age square are $\beta_{1}, \beta_{2}$ and $\beta_{3}$ respectively. The model is used separately for wage employees and self employees and for male and females across caste and region. The coefficient values of years of education measures the rate of return to each additional years of schooling of the individuals.

\section{Results And Discussion}

\subsection{Differences in education and earnings across gender, caste and region}

Our empirical study in Odisha shows that there are differences in earnings across gender, caste, region and occupations. Within each occupation, earnings differ sharply by gender, much lot lower for women (Table 1). The possible reason is that females work lower number of hours and months and they tend to be employed in lower income occupations than males. They are also involved in sporadically occupations (such as harvesting or home based occupation etc.) that generally have low incomes. Between occupations it was found that the differences in earnings between male and female are more in self employment than that in wage employment. Within any given occupation differences in earnings between male and female is less for backward (SCs/STs) people than forward (general) caste in both rural and urban areas. Backward people earn less compared to forward caste people and people in rural areas earn less than their urban counter part. The possible reason may be due to low level of literacy among the rural people, particularly among the backward caste population. 
Compared to higher caste category though the 'SCs/STs' are more likely to be employed, but their lower earned income suggests that, they are working at lower wages than their non-SC/ST counterparts.

\section{TABLE 1}

MEAN EDUCATION, EXPERIENCE AND EARNINGS OF THE SAMPLE POPULATION

\begin{tabular}{|c|c|c|c|c|c|c|c|c|c|}
\hline \multirow{3}{*}{$\begin{array}{c}\text { Social } \\
\text { Group }\end{array}$} & \multirow{2}{*}{$\begin{array}{c}\text { Age/ Education/ } \\
\text { Earnings }\end{array}$} & \multicolumn{4}{|c|}{ Wage Employment } & \multicolumn{4}{c|}{ Self Employment } \\
\cline { 2 - 10 } & & \multicolumn{2}{|c|}{ Rural } & \multicolumn{2}{c|}{ Urban } & \multicolumn{3}{c|}{ Rural } & \multicolumn{2}{c|}{ Urban } \\
\cline { 2 - 10 } & Male & Female & Male & Female & Male & Female & Male & Female \\
\hline \multirow{4}{*}{ SC } & Age (yrs) & 34.83 & 33.8 & 36.73 & 34.1 & 36.54 & 33.58 & 31.22 & 30.73 \\
\cline { 2 - 11 } & Education Yrs) & 10.01 & 9.2 & 10.45 & 9.68 & 9.65 & 9.23 & 10.67 & 9.33 \\
\cline { 2 - 10 } & Earning (Rs.) & 55417 & 49475 & 82679 & 72291 & 44526 & 46726 & 63144 & 58638 \\
\hline \multirow{4}{*}{ ST } & Age (yrs) & 33.23 & 32.12 & 41.39 & 38.73 & 40.91 & 37.19 & 35.4 & 33.89 \\
\cline { 2 - 10 } & Education Yrs) & 10.08 & 9.52 & 10.26 & 10.22 & 9.09 & 9.91 & 9.42 & 10.04 \\
\cline { 2 - 10 } & Earning (Rs.) & 64100 & 68040 & 58714 & 55191 & 44400 & 43993 & 65906 & 56929 \\
\hline \multirow{4}{*}{ General } & Age (yrs) & 36.23 & 32.12 & 41.39 & 38.73 & 40.91 & 37.19 & 35.4 & 37.89 \\
\cline { 2 - 10 } & Education Yrs) & 13.68 & 12.52 & 13.26 & 12.22 & 10.09 & 10.91 & 10.42 & 10.84 \\
\cline { 2 - 10 } & Earning (Rs.) & 144100 & 128040 & 148714 & 133191 & 92500 & 27993 & 109906 & 66929 \\
\hline
\end{tabular}

Source: Primary Survey, 2012

\subsection{Regression results: effects of education on earnings}

The preceding analysis clearly reveals the very fact that there are differences in earnings between gender (Male and female), occupation (wage employment and self employment), castes (backward and forward) and region (rural and urban) and within each occupation, caste and region. However, the extent of contribution of education to the earnings across gender, occupation, caste and region has not explained by the above analysis. Hence, we have attempted to examine the effect/contribution of education of male and female in terms of years of schooling on earning along with other determinants.

\subsection{Rate of return to education by gender, caste, occupation and region}

Table 2 and Table 3 present Ordinary Least Squares (OLS) estimates the return to education Odisha by gender, caste, occupation and region. It is clear that returns to education are significantly and substantially greater for women irrespective of occupations, castes and region. Return to education for backward caste people is more compared to forward caste across region and occupation. The return to education is more in rural areas than urban areas. Return is higher in case of wage employees than self employees. Across caste categories the highest rate of return in observed among STs followed by SCs and general castes in both occupations. The highest rate of return to education is observed in rural areas among wage employees particularly among ST females. It indicates that the effect of education in influencing earning of backward population in rural areas is important. The return to education for SCs in case of wage employees is 13.1 per cent and 11.7 per cent for the females and males in rural areas, the corresponding figures STs are 15.1 and 12.9, for general castes 11.2 and 9.5 for males and females respectively. This implies that if we increase one year of education for both male and female, their earnings are increased by 13.1 percent and 11.7 percent for SCs females and males and 15.1 percent and 12.9 percent for ST males and females and 11.2 and 9.5 for males and females for general castes respectively. A similar trend is also observed in urban areas. In case of self employment the rate of return to education 12.2 percent and 11.4 percent for SCs females and males and 14.2 percent and 12.2 percent for ST males and females and 11.1 and $9.6 \%$ for males and females for general castes respectively in rural areas. A similar result is observed in urban areas. All the coefficients of education are statistically significant at 1 percent level. 
TABLE 2

REGRESSION RESULTS OF EFFECT OF EDUCATION ON EARNINGS BY GENDER, CASTE AND REGION FOR SELF EMPLOYEES (Dependent Variable: Log of Earnings)

\begin{tabular}{|c|c|c|c|c|c|c|c|c|c|}
\hline Region & Caste & Gender & Intercept & Age & $\begin{array}{c}\text { Age } \\
\text { square }\end{array}$ & Education & $\begin{array}{c}\text { Adjusted } \\
\mathrm{R}^{2}\end{array}$ & $\mathrm{~F}$ & $\mathrm{~N}$ \\
\hline \multirow{6}{*}{ Rural } & \multirow{2}{*}{$\mathrm{SC}$} & Female & $\begin{array}{l}3.384 * \\
(9.793)\end{array}$ & $\begin{array}{c}0.001 \\
(0.035)\end{array}$ & $\begin{array}{c}0.0000 \\
(-0.138)\end{array}$ & $\begin{array}{c}0.131 * \\
(11.357)\end{array}$ & 0.641 & 44.44 & 30 \\
\hline & & Male & $\begin{array}{c}3.404^{*} \\
(12.503)\end{array}$ & $\begin{array}{c}0.053 \\
(2.164)\end{array}$ & $\begin{array}{c}0.0003 \\
(-1.213)\end{array}$ & $\begin{array}{l}0.117 * \\
(8.235)\end{array}$ & 0.755 & 58.43 & 30 \\
\hline & \multirow{2}{*}{ ST } & Female & $\begin{array}{l}4.324 * \\
(5.703)\end{array}$ & $\begin{array}{c}0.004 \\
(0.135)\end{array}$ & $\begin{array}{c}0.002 \\
(-0.168)\end{array}$ & $\begin{array}{l}0.151 * \\
(9.357)\end{array}$ & 0.641 & 44.44 & 30 \\
\hline & & Male & $\begin{array}{c}4.115^{*} \\
(6.221)\end{array}$ & $\begin{array}{c}0.001 \\
(0.374)\end{array}$ & $\begin{array}{l}-0.0001 \\
(-0.857)\end{array}$ & $\begin{array}{c}0.129 * \\
(4.007)\end{array}$ & 0.659 & 17.17 & 30 \\
\hline & \multirow{2}{*}{ General } & Female & $\begin{array}{l}2.093 * \\
(4.040)\end{array}$ & $\begin{array}{c}0.037 \\
(1.824)\end{array}$ & $\begin{array}{c}0.000 \\
(-0.566)\end{array}$ & $\begin{array}{c}0.112 * \\
(5.428)\end{array}$ & 0.573 & 28.65 & 30 \\
\hline & & Male & $\begin{array}{c}4.732 * \\
(12.103)\end{array}$ & $\begin{array}{c}0.018 \\
(1.377)\end{array}$ & $\begin{array}{c}0.000 \\
(-1.349)\end{array}$ & $\begin{array}{c}0.095^{*} \\
(8.389)\end{array}$ & 0.663 & 23.69 & 30 \\
\hline \multirow{6}{*}{ Urban } & \multirow{2}{*}{$\mathrm{SC}$} & Female & $\begin{array}{l}3.226 * \\
(6.671)\end{array}$ & $\begin{array}{c}0.026 \\
(0.916)\end{array}$ & $\begin{array}{l}-0.0003 \\
(-0.623)\end{array}$ & $\begin{array}{l}0.125^{*} \\
(6.696)\end{array}$ & 0.564 & 17.82 & 30 \\
\hline & & Male & $\begin{array}{c}3.615^{*} \\
(6.911)\end{array}$ & $\begin{array}{c}0.011 \\
(0.354) \\
\end{array}$ & $\begin{array}{l}-0.0001 \\
(-0.357)\end{array}$ & $\begin{array}{c}0.109 * \\
(4.507)\end{array}$ & 0.629 & 19.17 & 30 \\
\hline & \multirow{2}{*}{ ST } & Female & $\begin{array}{l}6.193^{*} \\
(4.220)\end{array}$ & $\begin{array}{c}0.037 \\
(1.824)\end{array}$ & $\begin{array}{c}0.000 \\
(-0.476)\end{array}$ & $\begin{array}{c}0.132 * \\
(5.428)\end{array}$ & 0.673 & 20.65 & 30 \\
\hline & & Male & $\begin{array}{l}3.023 * \\
(4.420)\end{array}$ & $\begin{array}{c}0.033 \\
(1.024)\end{array}$ & $\begin{array}{c}0.000 \\
(-0.258)\end{array}$ & $\begin{array}{c}0.122 * \\
(5.428)\end{array}$ & 0.593 & 22.60 & 30 \\
\hline & \multirow{2}{*}{ General } & Female & $\begin{array}{l}5.591 * \\
(6.387)\end{array}$ & $\begin{array}{c}0.029 \\
(1.962)\end{array}$ & $\begin{array}{c}0.000 \\
(-1.203)\end{array}$ & $\begin{array}{l}0.097 * \\
(7.182)\end{array}$ & 0.641 & 25.41 & 30 \\
\hline & & Male & $\begin{array}{c}3.158 * \\
(18.249)\end{array}$ & $\begin{array}{c}0.053 \\
(0.829) \\
\end{array}$ & $\begin{array}{c}0.000 \\
(-1.083)\end{array}$ & $\begin{array}{c}0.088 * \\
(9.006)\end{array}$ & 0.675 & 38.70 & 30 \\
\hline
\end{tabular}

Note: * Indicates significant at 1 per cent level, and Figures in the brackets are t-values

TABLE 3

\section{REGRESSION RESULTS OF EFFECT OF EDUCATION ON EARNINGS BY GENDER,} CASTE AND REGION FOR WAGE EMPLOYEES (Dependent Variable: Log of Earnings)

\begin{tabular}{|c|c|c|c|c|c|c|c|c|c|}
\hline Region & Caste & Gender & Intercept & Age & $\begin{array}{c}\text { Age } \\
\text { square }\end{array}$ & Education & $\begin{array}{c}\text { Adjusted } \\
\mathrm{R}^{2}\end{array}$ & $\mathrm{~F}$ & $\mathrm{~N}$ \\
\hline \multirow{6}{*}{ Rural } & \multirow{2}{*}{$\mathrm{SC}$} & Female & $\begin{array}{l}2.513 * \\
(3.137)\end{array}$ & $\begin{array}{c}0.054 \\
(1.194) \\
\end{array}$ & $\begin{array}{c}-0.005 \\
(-1.094)\end{array}$ & $\begin{array}{l}0.122 * \\
(8.209)\end{array}$ & 0.818 & 22.62 & 30 \\
\hline & & Male & $\begin{array}{c}3.146^{*} \\
(11.136) \\
\end{array}$ & $\begin{array}{c}0.035 \\
(1.273) \\
\end{array}$ & $\begin{array}{c}-0.003 \\
(-1.221) \\
\end{array}$ & $\begin{array}{l}0.114 * \\
(5.119)\end{array}$ & 0.517 & 18.92 & 30 \\
\hline & \multirow{2}{*}{ ST } & Female & $\begin{array}{l}4.012 * \\
(5.424)\end{array}$ & $\begin{array}{c}0.007 \\
(1.024)\end{array}$ & $\begin{array}{c}0.000 \\
(-0.258)\end{array}$ & $\begin{array}{l}0.142 * \\
(4.421)\end{array}$ & 0.673 & 19.52 & 30 \\
\hline & & Male & $\begin{array}{l}4.210 * \\
(3.103)\end{array}$ & $\begin{array}{c}0.010 \\
(1.027)\end{array}$ & $\begin{array}{c}0.000 \\
(-1.211)\end{array}$ & $\begin{array}{l}0.125 * \\
(5.356)\end{array}$ & 0.663 & 28.69 & 30 \\
\hline & \multirow{2}{*}{ General } & Female & $\begin{array}{l}3.205 * \\
(6.532)\end{array}$ & $\begin{array}{c}0.003 \\
(0.187) \\
\end{array}$ & $\begin{array}{c}0.000 \\
(-0.226)\end{array}$ & $\begin{array}{l}0.111 * \\
(3.295)\end{array}$ & 0.613 & 19.41 & 30 \\
\hline & & Male & $\begin{array}{l}4.086 * \\
(5.898)\end{array}$ & $\begin{array}{c}0.040 \\
(1.096)\end{array}$ & $\begin{array}{c}0.001 \\
(-0.958)\end{array}$ & $\begin{array}{l}0.096 * \\
(4.207)\end{array}$ & 0.478 & 15.98 & 30 \\
\hline \multirow{6}{*}{ Urban } & \multirow{2}{*}{$\mathrm{SC}$} & Female & $\begin{array}{c}4.324 * \\
(11.527) \\
\end{array}$ & $\begin{array}{c}0.029 \\
(1.341) \\
\end{array}$ & $\begin{array}{c}0.0004 \\
(-1.971)\end{array}$ & $\begin{array}{c}0.092 * \\
(10.592)\end{array}$ & 0.802 & 64.51 & 30 \\
\hline & & Male & $\begin{array}{l}3.418 * \\
(8.774) \\
\end{array}$ & $\begin{array}{c}0.018 \\
(0.938) \\
\end{array}$ & $\begin{array}{l}-0.0001 \\
(-0.591) \\
\end{array}$ & $\begin{array}{l}0.105 * \\
(7.766) \\
\end{array}$ & 0.455 & 20.20 & 30 \\
\hline & \multirow{2}{*}{ ST } & Female & $\begin{array}{l}3.426 * \\
(6.251)\end{array}$ & $\begin{array}{c}0.020 \\
(0.416) \\
\end{array}$ & $\begin{array}{c}-0.003 \\
(-0.583) \\
\end{array}$ & $\begin{array}{l}0.135 * \\
(4.586) \\
\end{array}$ & 0.664 & 27.25 & 30 \\
\hline & & Male & $\begin{array}{l}4.215 * \\
(4.011)\end{array}$ & $\begin{array}{c}0.001 \\
(0.854)\end{array}$ & $\begin{array}{c}-0.002 \\
(-0.897)\end{array}$ & $\begin{array}{l}0.119 * \\
(4.507)\end{array}$ & 0.699 & 21.10 & 30 \\
\hline & \multirow{2}{*}{ General } & Female & $\begin{array}{c}3.268 * \\
(10.868) \\
\end{array}$ & $\begin{array}{c}0.004 \\
(0.537) \\
\end{array}$ & $\begin{array}{c}0.000 \\
(-0.102) \\
\end{array}$ & $\begin{array}{l}0.082 * \\
(5.710)\end{array}$ & 0.531 & 20.21 & 30 \\
\hline & & Male & $\begin{array}{l}3.404 * \\
(7.256)\end{array}$ & $\begin{array}{c}0.029 \\
(1.541)\end{array}$ & $\begin{array}{c}0.000 \\
(-1.337)\end{array}$ & $\begin{array}{l}0.070 * \\
(6.526)\end{array}$ & 0.324 & 16.39 & 30 \\
\hline
\end{tabular}

Note: * Indicates significant at 1 per cent level, and Figures in the brackets are t-values 


\subsection{Returns to level of education by gender, caste and region}

The above regression results explained that an extra year of schooling for men and women enables them to earn more income in both the occupations, region and across caste. But, it did not say anything about different levels of education. We estimated the same equation for different levels of education using the same variables for self employees and wage employees. Since the coefficient values of education provide the returns to education we presented those values only in Table 4 . The returns to female education are always found to be higher compared to their male counterparts in all the levels of education irrespective of occupation, caste and region.

For self employees, the returns to elementary education is the highest followed by secondary and higher education across gender, castes and region. Return to education in rural areas is more compared to urban areas. An important aspect of high returns to an extra year of elementary education for self employees has to do with the quality and appropriateness of the education that is provided. Further, high return to education among lower caste females reflects the low level of literacy in rural areas particularly among the lower castes females.

For wage employees, the returns to education for both male and female increase with the increase in the levels of education across region and caste. In other words, the returns to higher education is the highest followed by secondary and elementary education across gender, social groups and region. Return to education is more in rural areas compared to urban areas and lower caste people earn more with increase in education. The fact that returns to education in wage employment is high for women particularly among SCs/STs in rural areas could reflect the scarcity of educated women, combined with the existence of jobs that require educated women, such as health workers (ASHA, Anganwadi workers, nurse etc.) and primary school teachers, which are predominantly female jobs.

It is further observed that within any given level of education, the differences in return to education across gender and region is very less for wage employees than in case of self employees. This may be due to the fact that in case of self employees there is irregularity of jobs, choice of work is limited, quality of education differs significantly, conservative attitude of the people etc. It is further observed that, the differences in returns to education between female and male, between lower caste and upper caste and between rural and urban areas decline at higher levels of education. This provides the plea that the inequality in earnings across gender, caste and region can be reduced substantially with the increase in the levels of education.

TABLE: 4

RETURNS TO EDUCATION BY GENDER, CASTE, REGION AND OCCUPATION

\begin{tabular}{|c|c|c|c|c|c|c|c|c|}
\hline \multirow{2}{*}{ Caste } & \multirow{2}{*}{ Region } & \multirow{2}{*}{ Gender } & \multicolumn{3}{|c|}{ Wage Employees } & \multicolumn{3}{|c|}{ Self Employees } \\
\hline & & & Elementary & Secondary & Higher & Elementary & Secondary & Higher \\
\hline \multirow{6}{*}{ Rural } & \multirow{2}{*}{ SC } & Male & 0.151 & 0.135 & 0.114 & 0.144 & 0.127 & 0.107 \\
\hline & & Female & 0.171 & 0.152 & 0.121 & 0.154 & 0.144 & 0.134 \\
\hline & \multirow{2}{*}{ ST } & Male & 0.162 & 0.142 & 0.119 & 0.155 & 0.134 & 0.122 \\
\hline & & Female & 0.178 & 0.163 & 0.128 & 0.164 & 0.145 & 0.134 \\
\hline & \multirow{2}{*}{ General } & Male & 0.130 & 0.120 & 0.115 & 0.123 & 0.112 & 0.108 \\
\hline & & Female & 0.145 & 0.124 & 0.119 & 0.138 & 0.116 & 0.112 \\
\hline \multirow{6}{*}{ Urban } & \multirow{2}{*}{ SC } & Male & 0.139 & 0.123 & 0.110 & 0.130 & 0.116 & 0.101 \\
\hline & & Female & 0.152 & 0.133 & 0.122 & 0.140 & 0.126 & 0.123 \\
\hline & \multirow{2}{*}{ ST } & Male & 0.143 & 0.131 & 0.120 & 0.134 & 0.120 & 0.111 \\
\hline & & Female & 0.158 & 0.154 & 0.132 & 0.148 & 0.137 & 0.129 \\
\hline & \multirow{2}{*}{ General } & Male & 0.121 & 0.116 & 0.106 & 0.112 & 0.104 & 0.097 \\
\hline & & Female & 0.136 & 0.125 & 0.110 & 0.127 & 0.108 & 0.101 \\
\hline
\end{tabular}

\section{Conclusions}

From the above discussion it is concluded that there are income differences by gender, caste, region and occupation in Odisha. Low level of education is one of the factors for income differences between male and female not only across castes, region and occupations but also within each caste, region and occupation. Further, the effect of education on the earnings is found to be very significant and quite substantial. It is further observed that, the differences in returns to education between female and male, between lower caste and upper caste and between rural and urban areas decline at higher levels of education in case of both the occupations. This provides the plea that the inequality in earnings across gender, caste and region can be reduced substantially with the increase in the levels of education. Hence, education is considered one of the strong instruments for reducing the inequality in earning in Odisha. In this backdrop our findings suggest that more educational 
opportunities to be provided in rural areas, special efforts to be taken to increase level of education of women and lower caste people. Further, Government should provide employment opportunities in rural areas to enhance work participation rate.

\section{References}

[1] M. Freeman, Labour markets, segments and shelters (New York, Allan Held osmun/universe, 1976).

[2] D. Mazumdar and M. Ahmed, Labour market segmentation and determination of earnings: a case study, World Bank, Mimeo, November, 1977.

[3] Thorat, S. \& K. Newman, Caste and economic discrimination: causes, consequences and remedies, Economic\& Political Weekly, 42(41), 2007, 4121-24.

[4] Jodhka, S. S. and G. Shah, Comparative contexts of discrimination: caste and untouchability in South Asia, Indian Institute of Dalit Studies, New Delhi, Working Paper Series, 4 (5), 2010.

[5] G. Becker, Human capital: a theoretical and empirical analysis with special reference to education (New York, Columbia University Press, 1964).

[6] J Mincer, On the job training: cost, returns and some implications, Journal of Political Economy, 82(5) part -2 (Supplement), 1962, S76-S108.

[7] T.W Schultz, Investment in human capital, American Economic Review, 57(1), 1961, 1-17.

[8] J.B.G Tilak, Economics of inequality in education (New Delhi, Sage Publication, 1987).

[9] S. Debi, Economics of higher education (Meerut, Anu books, 1983).

[10] S. Debi, S and A B Das, Education and labour market discrimination in gender perspectives: some evidence from KBK districts of Odisha, The Indian Journal of Labour Economics, 53(3), 2010, 537-546. 